\title{
Debt as a source of financial stress in Australian households
}

\author{
Andrew C. Worthington \\ School of Accounting and Finance, University of Wollongong, NSW, Australia
}

\begin{abstract}
This paper examines the role of demographic, socioeconomic and debt portfolio characteristics as contributors to financial stress in Australian households. The data is drawn from the most-recent Household Expenditure Survey and relates to 3,268 probability-weighted households. Financial stress is defined, amongst other things, in terms of financial reasons for being unable to have a holiday, have meals with family and friends, engage in hobbies and other leisure activities and general money management. Characteristics examined included family structure and composition, source and level of household income, age, sex and marital status, ethnic background, housing value, debt repayment of various types and credit card usage. Binary logit models are used to identify the source and magnitude of factors associated with financial stress. The evidence provided suggests that financial stress is higher in families with more children and those from ethnic minorities, especially when reliant on government pensions and benefits, and lower in families with higher disposable incomes and housing values. There is weak evidence that Australia's historically high levels of household debt cause financial stress.
\end{abstract}

Keywords Household and consumer debt, owner-occupied and investor housing, financial stress.

\section{Introduction}

Household debt has grown dramatically relative to disposable income over recent years, as has concern that this level of debt poses a threat to consumer wellbeing in many global economies. In the United States mortgage debt and consumer credit relative to disposable income are at or near all time record highs, with the primary driver being mortgage debt rising from less than 36 percent of disposable income to more than 66 percent in the last thirty years. ${ }^{1}$ In the United Kingdom there have been calls for 'close monitoring' of the growth in unsecured lending - some 19 percent of household debt up from 14 percent a decade ago and concern has also been expressed about total household debt - currently rising by 13 percent annually - and its possible impact on vulnerable lower-income and younger households. ${ }^{2,3}$ A similar picture emerges in other OECD economies with total household debt to income ratios rising from eighty percent or lower in the early 1980 s to at least 120 percent in the UK, Canada, Germany and the US, more than 130 percent in Japan, and 180 percent in the Netherlands. 
In Australia too there has been unease about the growth of household debt. ${ }^{4}$ In the decade to December 2002 the ratio of household debt to income rose from a level that was relatively low by international standards ( 56 percent) to one that is in the upper range for comparable economies (125 percent). This represents an average annual growth rate of 13.9 percent over the decade and 14.7 percent in the past five years. And while borrowing for owner-occupied housing still accounts for the major portion of this debt (85.5 percent) and much of its growth (15.3 percent in the last decade and 15.4 percent in the past five years), substantially faster growth rates are found in borrowing for investor housing (21.6 percent over the decade and 20.7 over the past five years) and credit cards (17.4 percent over the decade and 20.9 percent in the past five years). ${ }^{5}$

Reasons for the rapid growth in Australian household indebtedness are not hard to find. Lower mortgage interest rates (averaging 15 percent in the 1980 s and 7 percent in the late 1990s) and the fall in servicing costs by itself can account for an almost doubling of household borrowing. This is particularly the case when combined with the strong and sustained growth in housing prices, especially in the capital cities (56.9 percent across Australia and up to 89.3 percent in Melbourne and 62.0 percent in Brisbane from 19972002). ${ }^{6}$ At the same time, the low inflation environment of the late 1990s and early 2000s (averaging 2.6 percent), while necessary for the lower interest rate, has its own effect in that nominal income growth erodes the real value of debt less rapidly than in a high inflation environment.

Financial deregulation has also had a role to play. To start with, the increase in competition has meant that the reduction in lending margins of about 2 percent has been fully passed on to consumers. Similarly, loans for investor housing have risen dramatically as financial institutions have sought to expand their portfolios with loans on high-return, low-risk domestic properties, and by offering products with investors in mind such as split-purpose and interest only loans and deposit bonds. ${ }^{7}$ Finally, the development of new products, particularly home-equity loans and redraw facilities, has enabled households to more flexibly manage equity for building extensions and alterations and other investment and consumption purposes. For example, around 20 percent of borrowers refinancing home loans over the period 1997-99 used at least some of the proceeds to fund purchases such as cars and holidays. $^{8}$

Nevertheless, it is thought that these outwardly sound contributors to the growth in household debt obscure some changes that have increased its risk and thereby the exposure of Australian households to financial stress - defined as the adverse economic or social 
outcomes associated with a household's financial situation, including debt repayment problems, delinquency, bankruptcy and lack of discretionary income. To start with, much of the growth in total household debt can be attributed to the very strong growth of borrowing for investor housing. ${ }^{6}$ Because such borrowing is inherently riskier, and given its high exposure to inner city, multi-unit apartment markets with the immediate prospects of a glut in supply, it is argued that this exposes some households to a greater level of financial stress than is the case with purely owner-occupied housing. Since investor housing very often focuses on short-term capital gain, falling markets may expose households to a loss if the property is sold quickly, while holding on to the property may involve a longer repayment period than originally anticipated. Both outcomes are associated with financial stress: the former with the fall in household wealth and the latter with a reduction in disposable income.

Next, while aggregate debt servicing (ratio of interest payments to disposable income) has fallen, households have increased borrowing by proportionately more than the reduction in interest rates. ${ }^{5}$ As with aggregate gearing (the ratio of the value of housing debt to the stock of housing assets) this at first appears to have only increased modestly in the past five years, but since most Australian households hold no housing debt (about seventy percent own their home outright or rent) the effects are more pronounced than at first suggested (20 percent across all households but 43 percent in mortgaged households). This suggests that at least some Australian households may be exposed to a degree of financial stress because of their borrowing. That is, more income is being directed towards loan repayments and less is available for discretionary expenditure.

The purpose of the present paper is to add to the small but evolving consumer debt literature an analysis of financial stress in Australian households using the unit record files underlying the Australian Bureau of Statistics' Household Expenditure Survey. ${ }^{9}$ This survey focuses on the demographic, socioeconomic and financial characteristics of households and can be linked with these households' perceptions regarding financial stress, as variously measured. It thereby provides an important input into current economic policy regarding the impact of household debt on financial stress as compared to non-debt related influences. To the author's knowledge this is the first study of its kind, both in Australia and overseas, and adds significantly to the literature concerning the psychological impact of consumer debt. The paper itself is divided into four main areas. The first section briefly reviews the literature regarding consumer debt and household behaviour. The second section explains the empirical methodology and data employed in the analysis. The third section discusses the results. The paper ends with some concluding remarks. 


\section{Literature review}

The literature concerning the causes and consequences of household debt may be categorised into three areas: (i) attempts to explain differing household financial strategies, or the different patterns of financial assets and debts found in households, and link these with consumption, saving and borrowing behaviour; (ii) efforts to investigate the factors which are associated with the source, level and conditions of debt which a household demands and is granted or rejected; and (iii) endeavours which explore the issues related to insolvency in household finances, usually in terms of predictive models of debt repayments, delinquency and bankruptcy.

To start with, a small amount of empirical attention has been directed at analysing the linkage between household portfolio choices and other household behaviour. This is important because the impact of policies on households' saving and debt behaviour (and consumption) can vary across different groups in an economy in ways not reflected at the aggregate level. Gunnarsson and Wahlund, for example, categorised the financial choices of one thousand Swedish households into residual saving, contractual saving, security saving, risk hedging, prudent investing and 'divergent' strategies and examined the impact of financial planning and control, financial wealth and home ownership, and attitudes to risk taking across these categories. ${ }^{10}$ They concluded that contractual savers had a very heavy debt burden and relied upon credit cards, whereas residual savers had fewer loans and few even possessed credit cards. As an alternative, Viaud and Roland-Levey organised a typology of four classes defined along the lines of how households strived to build up their capital: namely, 'accumulating savers', 'prodigal households', 'prudent agents' and 'fragile borrowers'. ${ }^{11}$ Using the concept of social identity Viaud and Roland-Levey reasoned why households in different economic positions may in fact have the same sort of structural relationships regarding savings and credit.

Other work in this area has generally concentrated on the link between household portfolios and decisions regarding consumption or savings/borrowing. For example, de Ruiter and Smant examined the relationship between the household balance sheet and consumer durables expenditure. ${ }^{12}$ In particular, they addressed the potential impact of the excessive debt burdens built up by households and financial deregulation in the 1980s and questioned if it might be behind the slow recovery of OECD economies. While finding, not entirely unexpectedly, that household wealth was an important determinant of consumer expenditure; they found no evidence that the 'excessive' household debt ratios of the 1980s were directly 
responsible for slowing down consumer durables expenditure during the period of economic recovery. They concluded that an emphasis on debt-income ratios at the aggregate level was misleading and that it was "...probably merely an illustration of common failures to consolidate balance sheets on an appropriate level when discussing macroeconomic issues". 12 Lastly, Engelhardt examined the empirical link between house price appreciation and the saving/borrowing behaviour of homeowners during the 1980s. ${ }^{13}$ Interestingly, it was found that a savings asymmetry existed in that households that experience real gains in wealth do not change their saving/borrowing behaviour, rather all the savings offset was from households that experienced a real capital loss.

The second and generally more extensive area of research focuses on the demand for household debt. At least some part of this work is aimed at differentiating mortgage demand and housing demand, while others are concerned with the interactions between the choice of mortgage instrument and the role of mortgage rationing and liquidity constraints. Leece, for instance, used the UK Family Expenditure Survey to estimate reduced form mortgage demand equations to analyse the impact of market rationing and financial liberalisation on households. ${ }^{14}$ The main findings of this analysis were that there is significant cross-sectional variation regarding the demand for mortgages and that the choice of mortgage instrument involving saving in an alternative investment vehicle reflects important portfolio and liquidity consideration. Leece also examined the determinants of UK household mortgage debt, though using the British Household Panel Survey and in the context of the choice between floating or fixed interest rates. ${ }^{15}$ He concluded that no socioeconomic variables, including age and firsttime buyers and marital status, were significant factors in influencing this choice of mortgage instrument.

Demand functions for household debt have also been modelled in the United States. For example, using the Survey of Consumer Finance Crook examined the factors that determined whether a credit applicant was likely to be rejected and/or discouraged from future application and what variables significantly affected the demand for household debt. ${ }^{16}$ While it was concluded that household debt was a function of household age, income, size and employment status, it was largely invariant to the level of expected future interest rates. Alternatively, Ling and McGill used the American Housing Survey to simultaneously estimate mortgage debt level with house value. ${ }^{17}$ Ling and McGill found that larger debt values were often associated with greater value residences and with the level of household income, along with household mobility and other demographic variables. Breuckner, Jones, Hendershott et 
al. and Lea et al. have also examined the demand for household debt as a function of financial, demographic and socioeconomic factors. ${ }^{18,19,20,21,22,23,24,25}$

The final area of empirical research is concerned with consumer debt repayment in the context of household insolvency, delinquency and bankruptcy. Böheim and Taylor, for example, examined evictions and repossessions using the British Household Panel Survey. ${ }^{26}$ The results showed that previous experience of financial problems had a significant and positive association with the current financial situation and the probability of eviction, and that negative financial surprises were an important route into financial difficulties after controlling for life events such as divorce and loss of employment. Walker (1996) also examined a significant life event (childbirth) as a source of financial strain and presented evidence that psychological and behavioural variables had a considerable impact on being in or keeping out of debt. ${ }^{27}$ Canner and Luckett, DeVaney and Lytton, DeVaney, Domowitz and Sartain, Gropp et al., Kau and Keenan, Muelbauer and Cameron also analysed debt in the context of household repayment difficulties, insolvency and bankruptcy. ${ }^{28,29,30,31,32,33,34}$

This rather more sizeable area of empirical inquiry is generally consistent with DeVany and Lytton's survey evidence that many demographic and socioeconomic variables influence household debt repayment, the likelihood of default, the propensity for insolvency and ultimately bankruptcy. ${ }^{29}$ For example, renter and ethnic minority status, level of education and households with higher ratios of mortgage or consumer debt payments to income are often significant determinants of missed or slow debt payments. Similarly, DeVany and Hanna found that the age and income of the household head had a negative relationship with the propensity for insolvency, as did married couples. ${ }^{35}$ Alternatively, Lunt and Livingstone concluded that socio-demographic variables such as social class, age or the number of dependent children were not significant predictors of car debt repayment, though not so disposable income. ${ }^{36}$

When examining existing research on household debt, a number of salient points emerge. First, almost all of this work has been undertaken in the United States and, to a lesser extent, the United Kingdom. Relatively little attention has been paid to disaggregated sets outside of these financial milieus, not least in Australia. Second, there has been an overwhelming emphasis in studies examining problems associated with household debt to focus on extreme conditions such as insolvency and bankruptcy. Certainly, it is expected that households with potential repayment problems would experience less severe examples of financial stress long before these events take place, including cutting back on discretionary areas of consumption, and these are therefore suggestive of leading indicators of debt repayment problems. Finally, 
much of the existing literature pre-dates the increase in household debt levels found in the past five years. This is important because the full impact of sustained low interest rates and inflation and financial deregulation are only now being fully felt. That is, guidance could be had on the degree of financial stress that exists when debt service and gearing are at historical highs. It is with these considerations in mind that the present study is undertaken.

\section{Research method and data}

All data is obtained from the Australian Bureau of Statistics' Household Expenditure Survey Confidentialised Unit Record File and relate to a sample of 3,268 probability-weighted Australian households with at least some outstanding debt. The strength of this data is that it is a national survey concerning the demographic, socioeconomic and financial characteristics of Australian households and for the first time includes a number of items to identify financial stress in households. Unfortunately, it comprises a single cross-section so there is no meaningful way in which household behaviour in the most recent survey can be linked with the results of earlier surveys and many of the categories of income and expenditure can only be interpreted realistically at the household, as against the personal, level.

The analytical technique employed in the present study is to specify households' perceptions of financial stress as the dependent variable $(y)$ in a regression with demographic, socioeconomic and debt characteristics as explanatory variables $(x)$. Binary logit regression is useful here where the aim is to predict the presence of an outcome (in this case, financial stress) based on a set of predictor variables (the demographic, socioeconomic and debt characteristics thought to cause financial stress). It is similar to a linear regression model but is suited to models where the dependent variable is dichotomous (i.e. financial stress or no financial stress) rather than continuous. Accordingly, the following model is specified:

$$
\operatorname{Prob}(y=1)=\frac{1}{1+e^{-\beta^{\prime} x}}
$$

where $x$ comprises a set of characteristics posited to influence the presence of financial stress, $\beta$ is a set of parameters to be estimated and $e$ is the exponential. The coefficients imputed by the binary logit model provide inferences about the effects of the explanatory variables on the probability of financial stress.

The dataset employed is composed of four sets of information. All of the sets are derived from the survey responses. The first set of information relates to several different dimensions of financial stress and comprises the dependent variable in the binary logit model specified in 
equation (1). In the survey the respondents were asked whether their present standard of living was worse than two years ago, indicate whether it was for financial reasons that they did not have a holiday away for a least one week a year, have a night out once a fortnight, have friends or family over for a meal once a month, have a special meal once a week, buy second-hand clothes most of the time and do not spend time on leisure or hobby activities, and whether they spend more money than they get most weeks $(y=1)$. For standard of living the control was that the household living standard was better or the same as two years ago, for the next six responses that the household either engaged in the stated activity or did not because of non-financial reasons only, and for money management that the household broke even or saved money most weeks $(y=0)$. These eight binary variables comprise the dependent variables in eight separate analyses aimed at explaining the causes of financial stress in Australian households.

\section{$<$ TABLE 1 HERE $>$}

Selected descriptive statistics are provided in Table 1. Overall, 758 households (23.19 percent) believed their standard of living was worse than two years earlier, 914 (27.97 percent) could not afford a holiday for one week a year, 665 (20.35 percent) could not afford a night out once a fortnight, 140 (4.25 percent) could not afford to have friends or family over for a meal once a month, 347 (10.47 percent) could not afford a special meal once a week, 317 (9.70 percent) could not afford to buy brand new clothes most of the time and 278 (8.51 percent) could not afford to spend time on leisure or hobby activities. In terms of financial management, 2,204 households or 67.44 percent stated that the household usually spent more money than it received, as against breaking even or saving money most weeks. The internal reliability of these eight measures is relatively high $(\alpha=0.7299)$ suggesting broad agreement between the alternative dimensions of financial stress.

The next three sets of information are specified as explanatory variables in the binary logit regression models. The first of these sets of information relates to household demographic characteristics, the second to socioeconomic characteristics, and the final set to debt characteristics. The first two sets of information are generally comparable to those employed in studies of household debt repayment, insolvency and bankruptcy and are intended to proxy for the factors thought to be non-debt sources of financial stress. The third set of information is used to identify households with different levels of debt service as a means of establishing a connection with household financial stress beyond these factors. 
The set of demographic variables upon which the financial stress indicators are regressed are first examined. Whilst there is no unequivocal rationale for predicting the direction and statistical significance of many of these independent variables, their inclusion is consistent with both past studies of the determinants of household financial stress (as variously defined) and the presumed interests of policy-makers and other parties. For example, Böheim and Taylor used personal characteristics and demographics of the household head to help determine the level of transaction costs, preferences and attitudes to risk, and household structure concerning the number and ages of children as explanatory variables in their study of evictions and repossessions, while Ling and McGill included ethnic background as a means of controlling for variation in household risk preferences. ${ }^{26,17}$

The first six variables relate to household structure. These represent households composed respectively of couples and lone parents with children over 15 years of age, couples and lone parents with children 14 years or younger and couples and lone parents with children both under 14 years and over 15 years. The control for these variables is single person or couple only households. The next eleven variables relate to the sex, age, marital status and ethnic background of the household head. These are used as proxies for general characteristics including stage of life cycle, unobservable risk preferences and access to labour and credit markets. For instance, Böheim and Taylor reasoned non-whites may have experienced difficulties with debt payments because of a lack of familiarity with financial institutions or the differential access to credit, while Canner and Luckett found in a study of US households that divorced or separated and younger persons were more likely to experience debt repayment problems, as did DeVaney and Hanna. ${ }^{26,28,35}$ The variables specified include the sex, age and marital status of the household head, whether the household head was born in Oceania, Europe, the Middle East and North Africa, Asia, the Americas or Sub-Saharan Africa and the year of arrival in Australia. The respective control variables are male, unmarried and born in Australia household heads, respectively. The final two variables are included to reflect additional dimensions of household structure and characteristics. These are the number of income units (INU) and the number of dependents $(D E P)$ in each household. Ling and McGill, for example, identified two-wage earning households as a positive indicator of financial strain along with the number of children. ${ }^{17}$

The next group of variables relate to the income characteristics of each household. The first three variables are dummy variables indicating whether the principal source of household income is derived from self-employment, superannuation and investments or government pensions and benefits. The control is wages and salaries as the principal source of household 
income. In this instance, and holding income constant, it is hypothesised that the more fixed the level of permanent income and the lower the ability to earn extra income, the higher the level of financial stress. Böheim and Taylor likewise hypothesised that sources of income were a potential source of financial stress in that a household with a retired head was more likely to report housing finance difficulties than employees, and observing that in many cases self-employment predated indebtedness because of the interaction between businesses and the collateral provided by housing wealth. ${ }^{26}$

The next two variables indicate whether the principal residence is being bought or rented (control is owned outright). It is generally the case that transaction costs associated with owner-occupation are sizeable when compared to renting, while mortgaged households with large fixed payments and a general lack of mobility may be less able to adjust to changes in regional employment conditions. Lastly, the estimated value of the principal dwelling and the level of household disposable income are also included. All other things being equal, greater wealth and/or income should expose debt holders to a lower level of financial stress.

The final eight variables in Table 1 represent the indebtedness of households. The six debt service ratios used are calculated by dividing the weekly repayments (in dollars) for various categories of loans by disposable income. The categories examined are loans to buy or build this or other property, loans for alterations and additions to this or other property and loans for motor vehicles, holidays and other purposes. Broadly, the first two variables are loans for owner-occupied housing while the next two are loans for investor housing, though there may be some interplay between these and loans for other purposes due to the existence of equity loans and redraw facilities. A measure of personal debt is also included in the form of the number of household credit cards, which in the absence of available credit limit, is the closest approximation of credit card debt available. On average, loans to buy and build owneroccupied housing account for 34.52 percent of disposable income, loans for investor housing 4.47 percent, owner occupied and investor housing alterations and additions 0.67 and 0.22 percent respectively, and loans for motor vehicle, holidays and other purposes 6.06, 0.12 and 1.66 percent respectively. The average household also has 1.44 credit cards.

\section{Empirical findings}

The estimated coefficients and standard errors of the parameters for the binary logit regressions are provided in Table 2. Also included are the McFadden $R^{2}$ as an analogue for that used in the linear regression model and the Hannan-Quinn criteria as a guide to model 
selection. Models employing the entire set of explanatory variables were initially estimated (results not shown), followed by refined specifications obtained using forward stepwise regression. The refined models were always preferred in terms of the trade-off between comprehensiveness and complexity (under the Hannan-Quinn criteria) so only the refined models are shown. This allows a focus on the most significant factors affecting financial stress.

\section{$<$ TABLE 2 HERE $>$}

The first model discussed is that predicting financial stress by comparing the current standard of living with that two years previously. The estimated coefficients for seven variables are significant at the 10 percent level of significance or lower and conform to $a$ priori expectations. The estimated coefficients in the beginning specification indicate that couples with older and younger children, households with an older household head or one born in the Middle East and North Africa, households with more income units and more dependents, and households dependent on government pensions and benefits are more likely to indicate that their present standard of living is worse than two years earlier, while households with higher disposable incomes are less likely to respond in this manner. The three greatest influences on this viewpoint (marginal effect in brackets) is being from a North African and Middle Eastern background (3.1530), and being a couple with both younger and older children (1.8187) or one dependent on government pensions and benefits (1.5588). Interestingly, none of the parameters associated with household debt are significant, suggesting that demographic and, to a lesser extent, socioeconomic influences dominate perceptions of increasing financial stress.

Broad agreement is found with the estimated coefficients and signs on the estimated coefficients in the next six models where households' responses that it was for financial reasons that they did not have a holiday away for a least one week a year, have a night out once a fortnight, have friends or family over for a meal once a month, have a special meal once a week, buy second-hand clothes most of the time and do not spend time on leisure or hobby activities are specified as the dependent variables. In all of these regressions, financial stress is negatively associated with the value of the dwelling and disposable income and positively associated with the number of income units (with the exception of cannot afford special meals) and dependents, whether the principal source of household income is from government pensions and benefits and whether the household head is born in North Africa and the Middle East (with the exception of cannot afford other than second hand clothes). The 
remaining significant factors (with dependent variable) are couples with older children and lone parents with younger or older children, and recently arrived in Australia household heads (cannot afford holiday), older, married or de facto and self-employed household heads and those buying their own home (cannot afford night out), lone parents with older and younger children, household heads born in Asia and credit cards (cannot afford family or friends for meals), and lone parents with younger children, self-employed household heads and credit cards (cannot afford leisure or hobby activities). With the exception of the number of credit cards, whether the principal source of household income is from self-employment, and lone parents with younger children (cannot afford leisure or hobby activities only) all of the signs on the estimated coefficients are positive.

The results in the final regression in Table 2 is where financial stress in household money management (defined as spending more money than received most weeks) is regressed against the same set of explanatory variables. In this model, households with more income earning units, a larger number of dependents, those that rely principally on government pensions and benefits, renting households and those with higher repayments on loans for other purposes are more likely to spend more money than is received most weeks, whereas those with higher repayments on loans for buying and building owner-occupied housing and those with higher disposable incomes are less likely to experience this same problem. The greatest marginal effects on this form of financial stress are high repayments on loans for other purposes, households with larger number of income units and those dependent upon government pensions and benefits as the principal source of income.

At first impression, it would appear that debt has little role to play in determining financial stress in Australian households. In fact, only for general money management is the repayment of a loan both significant and conform to its hypothesised sign. Indeed, in regards to general money management, higher repayments on loans to buy or build owner-occupied property are associated with lower financial stress as measured. At the same time, the number of credit cards even where significant (cannot afford other than second hand clothes and leisure or hobby activities) is negative suggesting a contradiction with a priori reasoning. In the case of the latter, it is of course likely that better access to credit cards increases financial flexibility and therefore has a role in diminishing financial stress in all but the most extreme circumstances. For the former, redundant variable tests of loans to buy or build this or other property, loans for alternations and additions to this or other property and loans for motor vehicles, holidays and other purposes reject the null hypothesis of joint insignificance $(F$ statistics and $p$-values in brackets) for cannot afford holiday (3.99, 0.0000), cannot afford 
special meals $(1.93,0.0514)$, cannot afford other than second hand clothes $(5.77,0.0000)$, cannot afford leisure or hobby activities $(5.72,0.0000)$ and money management $(2.28$, 0.0194). This indicates that debt portfolios exert a weak but significant influence on financial stress, but this is offset by effects elsewhere. A real possibility is that households are currently willing to carry high levels of debt with little financial stress seemingly confident that the capital gains provided by strong owner-occupied and investor housing markets, access to equity loans and other household investments, and a low and stable outlook for inflation and mortgage interest rates will provide financial flexibility for the foreseeable future.

As a final requirement, the ability of the various models to accurately predict outcomes in terms of financial stress is examined. Table 3 provides the predicted results for each refined model and compares these to the probabilities obtained from a constant probability model. The probabilities in the constant probability model are the values computed from estimating a model that includes only an intercept term, and thereby correspond to the probability of correctly identifying financial stress on the basis of the proportion experiencing it in the sample.

To start with, consider the model where cannot afford a holiday away for at least one week a year is specified as the dependent variable. Of the 3,268 households in the sample, 2,354 either had a holiday or did not for some non-financial reason and 914 indicated that they could not afford such a holiday. Of these the constant probability model correctly predicts 1,696 cases (72.03 percent) as having 'no financial stress' (as defined) and 256 cases (27.97 percent) as having 'financial stress'. This represents the correct prediction of 1,952 cases (or 59.71 percent) of all households. By way of contrast, the estimated model correctly identifies 2,209 cases (93.84 percent) as not having financial stress and 249 cases (27.24 percent) as having financial stress. Thus, the model correctly identifies 2,458 of the 3,268 households (or 75.21 percent) in terms of financial stress or not. This indicates an absolute improvement of 25.92 percent over the constant probability model (in terms of the number of correct predictions) and a relative improvement of 38.40 percent (in terms of the number of incorrect predictions).

\section{$<$ TABLE 3 HERE $>$}

The refined model for the remaining seven dimensions of financial stress delivers a comparable level of correct and incorrect predictions. The total percentages of correct prediction across these models (percentage of correct predictions for constant probability models in brackets) are: standard of living 77.05 (64.37), cannot afford night out 79.83 
(67.58), cannot afford friends or family for meals 95.62 (91.86), cannot afford special meals 89.32 (81.26), cannot afford other than second hand clothes 90.33 (82.48), cannot afford leisure or hobby activities 91.40 (84.43) and money management 71.30 (56.08). Of course, these are 'in-sample' predictions and the results could differ if 'out-of-sample' data was made available.

Importantly, it can also be seen that there is little relative improvement between the constant probability and estimated models for cannot afford friends or family for meals or cannot afford special meals. An obvious factor is the very small proportion of households who do not undertake these most basic of social activities because of financial hardship. Likewise, the models generally do much better in predicting the absence of financial stress, and this is not necessarily the most natural focus of interest. For example, just 1.08 and 1.46 percent of financially stressed households are predicted correctly when the dependent variable is respectively cannot afford leisure or hobby activities or cannot afford special meals, though 91.52 percent of financially stressed households are predicted correctly when money management is specified as the dependent variable. Regardless, Hosmer-Lemeshow goodness-of-fit test statistics for all the models with the exception of cannot afford night out fail to reject the null hypotheses of no functional misspecification and we may conclude that the models are appropriate for predicting financial stress in Australian households.

\section{Concluding remarks and policy recommendations}

The present study uses binary logit models to investigate the role of demographic, socioeconomic and debt characteristics in determining financial stress in Australian households. The current paper extends empirical work in this area in at least two ways. First, it represents the first attempt using quantitative statistical techniques to model financial stress in Australian households. This provides an important starting point for future research in this area. Second, rather than focusing on progressively more acute life events such as problems with debt repayment, insolvency and bankruptcy as found in previous empirical work, this study examines financial stress as defined by the inability to engage in commonplace social functions and family leisure activities. No comparable study is then thought to exist elsewhere with a focus on financial stress at the margin rather than at the extreme. The evidence provided suggests that financial stress is very much a function of the demographic and socioeconomic characteristics of households and, to a lesser extent, debt portfolios. 
First, it has been shown that the primary causes of financial stress in Australian households are basic demographic characteristics. These include the presence of children, the number of dependents and income-earning units, the age of the household head, and also whether the householder was born and a recent immigrant from North Africa and the Middle East and, on occasion, Asia. Policies already in place such as governmental assistance with child support and childcare stand out, especially since being a lone parent is two to three times more likely to suffer financial stress than a couple in the same situation, but the underlying cause of financial stress in Middle Eastern households especially is unknown. One possibility is a general lack of financial literacy skills and management; another is the interplay of global political events and higher perceived risk in, say, labour and credit markets. Regardless of source, such impacts are significant with Middle Eastern households anywhere from two to four times more likely to suffer financial stress in a given situation.

Second, it has also been shown that household socioeconomic factors also have a role in fostering financial stress. Key factors here include the increase in financial stress when a household is dependent upon government pensions and benefits and the decrease in financial stress associated with higher values of owner-occupied housing and disposable income. By itself, a ten percent fall in housing values could be associated with up to an eight percent increase in the likelihood of being financial stressed, depending on the dimension employed. This is important because the prospective collapse of both the owner-occupied and investor property markets is feared for its potential impact on aggregate consumption and thereby macroeconomic stability.

Finally, the results indicate that, for the most part, the historically high levels of indebtedness by Australian households appear to have little impact at the margin on financial reasons for being unable to engage in basic social activity such as having family and friends over for meals, having a night out, going on holiday or engaging in hobbies and other leisure activities. A key likelihood is that the very strong owner-occupied and investor housing market coupled with historically (and forecast to continue) low mortgage interest rates provides reassurance to households taking out debt, which in the main, is focused on housingrelated purposes. Households have also used a variety of other strategies to cope with the growth in indebtedness including refinancing with lower interest rates, extending the term of housing loans and substituting mortgage borrowing for more expensive consumer debt. That debt-related financial stress that does exist is not associated with housing, motor vehicle or holiday debt and thereby relates largely to unsecured debt. That said credit cards themselves seem to offer much in reducing financial stress for Australian households, reinforcing the 
view that they use the flexibility of this form of debt to maintain basic social and consumption activities.

There are, of course, a number of limitations in this study, all of which suggest further areas of research. To start with, the results of this analysis are framed around what could be regarded as relatively mild forms of financial stress; that is, the inability to engage in basic social activities such as meals with family and friends, nights out, holidays, etc. Certainly, most work in this area has emphasised the more extreme forms of financial stress, including insolvency and bankruptcy, and it may be that predictive modelling in that instance could be relatively more accurate, especially when using the demographic, socioeconomic and financial characteristics employed in this study.

Another possibility is that the current study has not addressed how households manage financial stress in terms of substituting between activities or reducing the frequency of these activities. In particular, little is known about how households use sources of emergency finance to maintain consumption with temporary changes in income and wealth, even though there is some evidence that this practice, though unsustainable in the longer term, is increasing. Finally, there is renewed concern in Australia over the prohibitive costs of owneroccupied housing, especially for young first-home buyers. In this study age did not appear to be a determining factor of financial stress, though in view of the life cycle approach to household debt this may not be the case in a subset of younger households.

\section{References}

1. Maki, D. M. (2000). The growth of consumer credit and the household debt service burden. Board of Governors of the Federal Reserve System Working Paper, 2000/12.

2. Nickell, S. (2003). House prices, household debt and monetary policy. Bank of England Quarterly Bulletin, 43, 131-136.

3. Scheherazade, D. (2002). Consumer debt rising and worsening, warns bank: Financial stability review alarm over house buyers' borrowing and spiralling debt among vulnerable groups. Financial Times, 12 December, 3.

4. McFarlane, I.J. (2003) Do Australian households borrow too much? [WWW document]. URL http://www.rba.gov.au/.

5. Reserve Bank of Australia (2003) Household debt: What the data show. Reserve Bank of Australia Bulletin, March, 1-11.

6. Reserve Bank of Australia (2002) Recent developments in housing: Prices, finance and investor attitudes. Reserve Bank of Australia Bulletin, July, 1-6.

7. Reserve Bank of Australia (2002) Innovations in the provision of finance for investor housing. Reserve Bank of Australia Bulletin, December, 1 - 6

8. Reserve Bank of Australia (2003) Housing equity withdrawal. Reserve Bank of Australia Bulletin, February, 50-54

9. Australian Bureau of Statistics (2002) 1998-99 Household Expenditure Survey Australia, Confidentialised Unit Record File, ABS. Cat. No. 6544.0.30.001.

10. Gunnarsson, J. \& Wahlund, R. (1997) Household financial strategies in Sweden: An exploratory study. Journal of Economic Psychology, 18, 201-233. 
11. Viaud, J. and Roland-Levy, C. (2000). A positional and representational analysis of consumption: Households when facing debt and credit. Journal of Economic Psychology, 21, 411-432.

12. DeRuiter, M. \& Smant, D. J. (1999) The household balance sheet and durable consumer expenditures: An empirical investigation for The Netherlands, 1972-93. Journal of Policy Modelling, 21, 243-274.

13. Engelhardt, G. V. (1996) House prices and homeowner savings behaviour. Regional Science and Urban Economics, 26, 313-336.

14. Leece, D. (2000) Choice of mortgage instrument, liquidity constraints and the demand for housing debt in the UK. Applied Economics, 32, 1121-1132.

15. Leece, D. (2000). Household choice of fixed versus floating rate debt: A binomial probit model with correction for classification error. Oxford Bulletin of Economics and Statistics, 62, 61-82.

16. Crook, J. (2001) The demand for household debt in the USA: Evidence from the 1995 Survey of Consumer Finance. Applied Financial Economics, 11, 83-91.

17. Ling, D.C. \& McGill, G. A. (1998). Evidence on the demand for mortgage debt by owner-occupants. Journal of Urban Economics, 44, 391-414.

18. Brueckner, J.K. (1994) The demand for mortgage debt: Some basic results. Journal of Housing Economics, 3, 1-21.

19. Brueckner, J.K. (1997) Consumption and investment motives and the portfolio choices of homeowners. Journal of Real Estate Finance and Economics, 15, 159-180.

20. Jones, L.D. (1993) The demand for home mortgage debt. Journal of Urban Economics, 33, 10-28.

21. Jones, L.D. (1994) Home mortgage debt financing of non-housing investments. Journal of Real Estate Finance and Investment, 9, 91-112.

22. Jones, L.D. (1995) Net wealth, marginal tax rates and the demand for home mortgage debt. Regional Science and Urban Economics, 25, 297-322.

23. Hendershott, P. H., LaFayette, W.C. \& Haurin, D.R. (1997) Debt usage and mortgage choice: The FHAconventional decision. Journal of Urban Economics, 41, 202-217.

24. Lea, S.E.G., Webley, P. \& Levine, R.M. (1993) The economic psychology of consumer debt. Journal of Economic Psychology, 14, 85-119.

25. Lea, S.E.G., Webley, P. \& Levine, R.M. (1995) Psychological factors in consumer debt: Money management, economic socialisation and credit use. Journal of Economic Psychology, 16, 681-701.

26. Böheim, R. \& Taylor, M. (2000) My home was my castle: Evictions and repossessions in Britain. Journal of Housing Economics, 9, 287-319.

27. Walker, C. M. (1996). Financial management, coping and debt in households under financial strain. Journal of Economic Psychology, 17, 789-807.

28. Canner, G.B. \& Luckett, C.A. (1991) Consumer debt repayment woes: Insights from a household survey. Journal of Retail Banking, 12, 55-62.

29. DeVaney, S. A. \& Lytton, R.H. (1995) Household insolvency: A review of household debt repayment, delinquency and bankruptcy. Financial Services Review, 4, 137-156.

30. DeVany, S.A. (1994) The usefulness of financial ratios as predictors of household insolvency: Two perspectives. Financial Counselling and Planning, 5, 5-24.

31. Domowitz, I. \& Sartain, R. (1999) Determinants of the consumer bankruptcy decision. Journal of Finance, 54, 403-420.

32. Gropp, R., White, M.J. \& Scholz, J.K. (1997) Personal bankruptcy and credit supply and demand. Quarterly Journal of Economics, 112, 217-251.

33. Kau, J.B. \& Keenan, D.C. (1999) Patterns of rational mortgage default. Regional Science and Urban Economics, 29, 765-785.

34. Muelbauer, J. \& Canmeron, G. (1997) A regional analysis of mortgage possessions: Causes, trends and future prospects. Housing Finance, 34, 25-34.

35. DeVany, S.A. \& Hanna, S. (1994) The effect of marital status, income, age and other variables on insolvency in the USA. Journal of Consumer Studies and Home Economics, 18, 293-303.

36. Lunt, P. \& Livingstone, S. (1992) Predicting personal debt and debt repayment: Psychological, social and economic determinants. Journal of Economic Psychology, 13, 111-134. 
Table 1 Variable definitions and descriptive statistics

\begin{tabular}{|c|c|c|c|}
\hline Variable & Definition & Mean & Std. dev. \\
\hline Standard of living & 1 if living standard worse than two years ago; 0 otherwise & 0.231 & 0.422 \\
\hline Cannot afford holiday & 1 if cannot afford holiday away at least one week a year; 0 otherwise & 0.279 & 0.448 \\
\hline Cannot afford night out & 1 if cannot afford a night out once a fortnight; 0 otherwise & 0.203 & 0.402 \\
\hline Cannot afford friends or family for meals & 1 if cannot afford to have friends or family over for a meal once a month; 0 otherwise & 0.042 & 0.201 \\
\hline Cannot afford special meals & 1 if cannot afford a special meal once a week; 0 otherwise & 0.104 & 0.306 \\
\hline Cannot afford other than second hand clothes & 1 if cannot afford clothes other than second hand clothes most of the time; 0 otherwise & 0.097 & 0.296 \\
\hline Cannot afford leisure or hobby activities & 1 if cannot afford to spend time on leisure or hobby activities; 0 otherwise & 0.085 & 0.279 \\
\hline Money management & 1 if spend more money than get most weeks; 0 otherwise & 0.674 & 0.468 \\
\hline Couple with older children & 1 if couple with children over 15 years of age; 0 otherwise & 0.111 & 0.314 \\
\hline Couple with younger children & 1 if couple with children 14 years or younger; 0 otherwise & 0.308 & 0.461 \\
\hline Couple with older and younger children & 1 if couple with children both under 14 years and over 15 years; 0 otherwise & 0.073 & 0.261 \\
\hline Lone parent with older children & 1 if lone parent with children over 15 years of age; 0 otherwise & 0.032 & 0.176 \\
\hline Lone parent with younger children & 1 if lone parent with children 14 years or younger; 0 otherwise & 0.042 & 0.201 \\
\hline Lone parent with older and younger children & 1 if lone parent with children both under 14 years and over 15 years; 0 otherwise & 0.011 & 0.107 \\
\hline Female household head & 1 of female household head; 0 otherwise & 0.341 & 0.474 \\
\hline Age of household head & Age of household head defined in fifteen ascending age groups from under 14 years to 75 years or over & 7.627 & 2.295 \\
\hline Widowed, divorced or separated household head & 1 if household head widowed, divorced or separated; 0 otherwise & 0.132 & 0.339 \\
\hline Married or de facto household head & 1 if household head married or in de facto relationship; 0 otherwise & 0.731 & 0.443 \\
\hline Born in Oceania & 1 if household head born in Oceania (excluding Australia); 0 otherwise & 0.034 & 0.182 \\
\hline Born in Europe & 1 if household head born in Europe; 0 otherwise & 0.141 & 0.348 \\
\hline Born in Middle East and North Africa & 1 if household head born in Middle East and North Africa; 0 otherwise & 0.011 & 0.105 \\
\hline Born in Asia & 1 if household head born in Asia; 0 otherwise & 0.052 & 0.223 \\
\hline Born in North and South America & 1 if household head born in North and South America; 0 otherwise & 0.009 & 0.098 \\
\hline Born in Sub-Saharan Africa & 1 if household head born in Sub-Saharan Africa; 0 otherwise & 0.009 & 0.095 \\
\hline Year of arrival in Australia & Year of arrival of household head from 1981 onwards & 0.477 & 1.014 \\
\hline Number of income units & Number of income units in household & 1.298 & 0.615 \\
\hline Number of dependents & Number of dependents in household & 1.040 & 1.178 \\
\hline Self employment & 1 if principal source of household income from self employment; 0 otherwise & 0.066 & 0.249 \\
\hline Superannuation and investments & 1 if principal source of household income from superannuation and investments; 0 otherwise & 0.017 & 0.130 \\
\hline Government pensions and benefits & 1 if principal source of household income from government pensions and benefits; 0 otherwise & 0.103 & 0.304 \\
\hline Principal dwelling being bought & 1 if principal dwelling being bought; 0 otherwise & 0.652 & 0.476 \\
\hline Principal dwelling being rented & 1 if principal dwelling being rented; 0 otherwise & 0.217 & 0.412 \\
\hline Value of principal dwelling & Estimated value of principal dwelling (\$ hundreds of thousands) & 1.469 & 1.321 \\
\hline Disposable income & Weekly household disposable income (\$ thousands) & 0.895 & 0.462 \\
\hline Buy or build this property & Weekly repayments on loan to buy or build this property divided by disposable income & 0.345 & 6.037 \\
\hline Buy or build other property & Weekly repayments on loan to buy or build other property divided by disposable income & 0.044 & 1.539 \\
\hline Alternations and additions to this property & Weekly repayments on loan for alternations and additions to this property divided by disposable income & 0.006 & 0.03 \\
\hline Alternations and additions to other property & Weekly repayments on loan for alternations and additions to other property divided by disposable income & 0.002 & 0.059 \\
\hline Buy motor vehicle & Weekly repayments on loan to buy motor vehicle divided by disposable income & 0.060 & 0.425 \\
\hline Loan for holiday & Weekly repayments on loan for a holiday divided by disposable income & 0.001 & 0.010 \\
\hline Loan for another purpose & Weekly repayments on loan for another purpose divided by disposable income & 0.016 & 0.067 \\
\hline Credit cards & Number of credit cards in household & 1.436 & 1.161 \\
\hline
\end{tabular}


Table 2 Parameter estimates of the binary logit models

\begin{tabular}{|c|c|c|c|c|c|c|c|c|c|c|c|c|c|c|c|c|}
\hline \multirow[t]{2}{*}{ Variable } & \multicolumn{2}{|c|}{ Standard of living } & \multicolumn{2}{|c|}{$\begin{array}{l}\text { Cannot afford } \\
\text { holiday }\end{array}$} & \multicolumn{2}{|c|}{$\begin{array}{l}\text { Cannot afford night } \\
\text { out }\end{array}$} & \multicolumn{2}{|c|}{$\begin{array}{l}\text { Cannot afford } \\
\text { friends or family for } \\
\text { meals }\end{array}$} & \multicolumn{2}{|c|}{$\begin{array}{l}\text { Cannot afford } \\
\text { special meals }\end{array}$} & \multicolumn{2}{|c|}{$\begin{array}{l}\text { Cannot afford } \\
\text { other than second } \\
\text { hand clothes }\end{array}$} & \multicolumn{2}{|c|}{$\begin{array}{l}\text { Cannot afford } \\
\text { leisure or hobby } \\
\text { activities }\end{array}$} & \multicolumn{2}{|c|}{$\begin{array}{c}\text { Money } \\
\text { management }\end{array}$} \\
\hline & 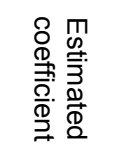 & $\frac{\stackrel{0}{0}}{\stackrel{\frac{0}{3}}{\frac{1}{2}}}$ & 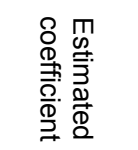 & 일 & 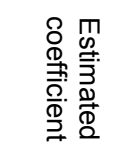 & $\frac{\stackrel{0}{0}}{\frac{0}{0}}$ & 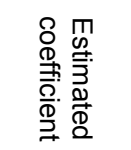 & 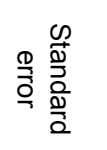 & 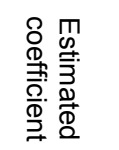 & $\frac{\stackrel{0}{0}}{\frac{0}{3}}$ & 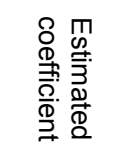 & 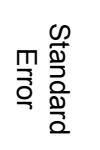 & 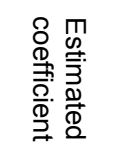 & $\frac{\stackrel{c}{0}}{\frac{0}{3}}$ & 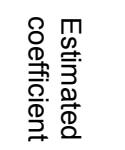 & $\frac{\stackrel{0}{0}}{\frac{0}{0}}$ \\
\hline Constant & $-1.294^{* *+1}$ & 0.193 & -0.194 & 0.149 & $-1.914^{* *+*}$ & 0.237 & $-2.553^{\text {*t+t }}$ & 0.315 & $-1.201^{* *+}$ & 0.183 & $-1.458^{\text {**t+ }}$ & 0.227 & $-1.482^{\text {*t+ }}$ & 0.236 & $0.647^{* *+}$ & 0.126 \\
\hline Couple with older children & - & - & $0.350^{* *}$ & 0.158 & - & - & - & - & - & - & - & - & - & - & - & - \\
\hline Couple with older and younger children & $0.343^{* *}$ & 0.168 & - & - & - & - & - & - & - & - & - & - & - & - & - & - \\
\hline Lone parent with older children & - & - & $0.613^{*+*+t}$ & 0.226 & - & - & - & - & - & - & - & - & - & - & - & - \\
\hline Lone parent with younger children & - & - & $0.943^{* *}$ & 0.383 & - & - & - & - & - & - & - & - & $-0.657^{* *}$ & 0.282 & - & - \\
\hline Lone parent with older and younger children & - & - & - & - & - & - & $1.298^{* * *}$ & 0.423 & - & - & - & - & - & - & - & - \\
\hline Age of household head & $0.054^{* * *}$ & 0.018 & _- & _- & $0.094^{*+* x}$ & 0.022 & - & - & - & - & - & - & _- & _- & - & - \\
\hline Married or de facto & - & - & - & - & $0.565^{* * *}$ & 0.125 & - & - & - & - & - & - & - & - & - & - \\
\hline Born in Middle East and North Africa & $0.876^{* *}$ & 0.343 & $1.383^{* * * t}$ & 0.394 & $0.987^{*+*}$ & 0.370 & $1.481^{* * *}$ & 0.470 & $0.860^{* *}$ & 0.393 & - & - & $1.048^{* * *}$ & 0.399 & - & - \\
\hline Born in Asia & - & - & - & - & - & - & $0.788^{* *}$ & 0.322 & - & - & - & - & - & - & - & - \\
\hline Year of arrival in Australia & - & - & $0.105^{* * * *}$ & 0.040 & - & - & - & - & - & - & - & - & - & _- & - & - \\
\hline Number of income units & $0.366^{* * * t}$ & 0.078 & $0.346^{*+*}$ & 0.088 & $0.240^{* *}$ & 0.099 & $0.734^{* * * t}$ & 0.166 & - & _- & $0.571^{* * *}$ & 0.125 & $0.516^{* * *}$ & 0.126 & $0.672^{* * *}$ & 0.076 \\
\hline Number of dependents & $0.106^{* * *}$ & 0.040 & $0.334^{*+* t}$ & 0.037 & $0.495^{* * * *}$ & 0.042 & $0.331^{* *+*}$ & 0.074 & $0.342^{* * * t}$ & 0.047 & $0.485^{*+*}$ & 0.051 & $0.372^{* * * *}$ & 0.053 & $0.437^{*+*}$ & 0.039 \\
\hline Self employment & - & - & - & - & $-0.437^{* *}$ & 0.197 & - & - & - & - & - & - & $-0.699^{* *}$ & 0.327 & - & - \\
\hline Government pensions and benefits & $0.366^{* * t+}$ & 0.140 & $0.586^{* * * t}$ & 0.141 & $0.411^{* * *}$ & 0.153 & $0.632^{* * *}$ & 0.238 & $0.649^{* *+*}$ & 0.166 & $0.616^{* *+*}$ & 0.175 & $0.393^{* *}$ & 0.188 & $0.578^{* * *}$ & 0.190 \\
\hline Principal dwelling being bought & - & - & - & - & $0.242^{* *}$ & 0.116 & - & - & - & - & - & - & - & - & - & - \\
\hline Principal dwelling being rented & - & - & - & - & - & - & - & - & - & - & - & - & - & - & $0.266^{* *}$ & 0.104 \\
\hline Value of principal dwelling & - & - & $-0.205^{* * *}$ & 0.040 & $-0.260^{* * *+}$ & 0.054 & $-0.427^{4 * *+}$ & 0.107 & $-0.205^{* * *}$ & 0.060 & $-0.370^{* * *}$ & 0.071 & $-0.204^{* * *}$ & 0.067 & - & - \\
\hline Disposable income & -1.196 & 0.135 & -1.568 & 0.153 & $-1.671^{* * *+}$ & 0.174 & $-2.420^{* * *}$ & 0.410 & $-1.601^{* * *}$ & 0.220 & $-2.063^{* * *}$ & 0.273 & $-2.034^{* * *}$ & 0.274 & $-1.444^{* \star *}$ & 0.109 \\
\hline Buy or build this property & - & - & - & - & - & - & - & - & - & - & - & - & - & - & $-0.014^{*}$ & 0.009 \\
\hline Loan for another purpose & - & - & - & - & - & - & - & - & - & - & - & - & - & - & $2.915^{* * *}$ & 1.098 \\
\hline Credit cards & - & - & $-0.1678^{*+*}$ & 0.041 & - & - & - & - & - & - & $-0.217^{*}$ & 0.068 & $-0.189^{* * *}$ & 0.068 & - & - \\
\hline McFadden $\mathrm{R}^{2}$ & & 0.052 & & 0.1330 & & 0.133 & & 0.177 & & 0.113 & & 0.177 & & 0.125 & & 0.102 \\
\hline Hannan-Quinn criteria & & 1.036 & & 1.0430 & & 0.889 & & 0.300 & & 0.601 & & 0.533 & & 0.521 & & 1.143 \\
\hline
\end{tabular}

${ }^{*} p \leq 0.10 ;{ }^{* *} p \leq 0.05 ;{ }^{* * *} p \leq 0.01$ 
TABLE 3 Observed and predicted values of the binary logit models

\begin{tabular}{|c|c|c|c|c|c|c|c|c|c|c|}
\hline & \multicolumn{2}{|c|}{ Observed } & \multicolumn{3}{|c|}{$\begin{array}{c}\text { Constant probability } \\
\text { model }\end{array}$} & \multicolumn{3}{|c|}{$\begin{array}{c}\text { Estimated } \\
\text { model }\end{array}$} & \multicolumn{2}{|c|}{$\begin{array}{c}\text { Hosmer- } \\
\text { Lemeshow }\end{array}$} \\
\hline \multirow{4}{*}{ Standard of living } & & & No & Yes & $\%$ & No & Yes & $\%$ & Statistic & $p$-value \\
\hline & No & 2510 & 1928 & 582 & 76.81 & 2494 & 16 & 99.36 & 7.370 & 0.497 \\
\hline & Yes & 758 & 582 & 176 & 23.19 & 734 & 24 & 3.17 & & \\
\hline & Total & 3268 & 2510 & 758 & 64.37 & 3228 & 40 & 77.05 & & \\
\hline \multirow{3}{*}{ Cannot afford holiday } & No & 2354 & 1696 & 658 & 72.03 & 2209 & 145 & 93.84 & 8.060 & 0.427 \\
\hline & Yes & 914 & 658 & 256 & 27.97 & 665 & 249 & 27.24 & & \\
\hline & Total & 3268 & 2354 & 914 & 59.71 & 2874 & 394 & 75.21 & & \\
\hline \multirow{3}{*}{ Cannot afford night out } & No & 2603 & 2073 & 530 & 79.65 & 2525 & 78 & 97.00 & 18.716 & 0.016 \\
\hline & Yes & 665 & 530 & 135 & 20.35 & 581 & 84 & 12.63 & & \\
\hline & Total & 3268 & 2603 & 665 & 67.58 & 3106 & 162 & 79.83 & & \\
\hline \multirow{3}{*}{$\begin{array}{l}\text { Cannot afford friends } \\
\text { or family for meals }\end{array}$} & No & 3129 & 2996 & 133 & 95.75 & 3122 & 7 & 99.78 & 5.586 & 0.693 \\
\hline & Yes & 139 & 133 & 6 & 4.25 & 136 & 3 & 2.16 & & \\
\hline & Total & 3268 & 3129 & 139 & 91.86 & 3258 & 10 & 95.62 & & \\
\hline \multirow{3}{*}{$\begin{array}{l}\text { Cannot afford special } \\
\text { meals }\end{array}$} & No & 2926 & 2620 & 306 & 89.53 & 2914 & 12 & 99.59 & 4.207 & 0.838 \\
\hline & Yes & 342 & 306 & 36 & 10.47 & 337 & 5 & 1.46 & & \\
\hline & Total & 3268 & 2926 & 342 & 81.26 & 3251 & 17 & 89.32 & & \\
\hline \multirow{4}{*}{$\begin{array}{l}\text { Cannot afford other } \\
\text { than second hand } \\
\text { clothes }\end{array}$} & No & 2951 & 2665 & 286 & 90.30 & 2928 & 23 & 99.22 & 3.070 & 0.929 \\
\hline & Yes & 317 & 286 & 31 & 9.70 & 293 & 24 & 7.57 & & \\
\hline & Total & 3268 & 2951 & 317 & 82.48 & 3221 & 47 & 90.33 & & \\
\hline & No & 2990 & 2736 & 254 & 91.49 & 2984 & 6 & 99.80 & 10.529 & 0.229 \\
\hline \multirow{3}{*}{$\begin{array}{l}\text { Cannot afford leisure } \\
\text { or hobby activities }\end{array}$} & Yes & 278 & 254 & 24 & 8.51 & 275 & 3 & 1.08 & & \\
\hline & Total & 3268 & 2990 & 278 & 84.43 & 3259 & 9 & 91.40 & & \\
\hline & No & 1064 & 346 & 718 & 32.56 & 313 & 751 & 29.42 & 11.873 & 0.156 \\
\hline \multirow[t]{2}{*}{ Money management } & Yes & 2204 & 718 & 1486 & 67.44 & 187 & 2017 & 91.52 & & \\
\hline & Total & 3268 & 1064 & 2204 & 56.08 & 500 & 2768 & 71.30 & & \\
\hline
\end{tabular}

Observed is the number of No and Yes responses in the sample; the probabilities in the constant probability model correspond to the probability of correctly identifying No and Yes responses on the basis of their proportion in the sample; the estimated model corresponds to the results in Table 3. \% - is the number of correct predictions for each response (i.e. No or Yes) as a percentage of the observed values for No and Yes; Total percent correct is the number of correct predictions (i.e. No and Yes) as a percentage of the total observed values for No and Yes. 